\title{
Pastoral fallow for improving low fertility hill country pastures
}

\author{
A.D. MACKAY', P.J. BUDDING', D.J. ROSS ${ }^{2}$ \\ K.R. TATE ${ }^{2}$, V.A. ORCHARD*. P.B.S. HART ${ }^{2}$ and H.A. KETTLES ${ }^{2}$ \\ ${ }^{I} D S I R$ Grasslands, Private Bag, Palmerston North \\ ${ }^{2}$ DSIR Land Resources, Private Bag, Lower Hutt
}

\begin{abstract}
The effect of a pastoral fallow (the 'spelling' of a pasture from early spring (September) to autumn (April/May)), with or without added fertiliser, on pasture and legume growth rates, total pasture biomass accumulation, nitrogen fixation, and on soil carbon and nitrogen cycling in the year of the fallow,andin theyearafterthefallow, wasevaluated on 2.2 ha of moderate to stceplow fertility, summermoist hill country at Ballantrae, DSIR Grasslands Hill Country Research Station.

The major effect was to open the sward, increase individual plant size, vigour and rooting depth, increase the presence and vigour of white clover by creating new niches for growth, and improve $\mathrm{N}$ fixation by legumes in the year after the fallow only. The data on soil $\mathrm{C}$ and $\mathrm{N}$ dynamics are consistent with the concept of fallowing adding a pool of potentially available $\mathrm{N}$ to the soil. The benefits of a fallow for moist hill country and other pastoral farming systems are discussed.
\end{abstract}

Keywords pastoral fallow, hill pastures, nitrogen, legume growth

\section{Introduction}

Capital dressings of superphosphate to encourage legume growth and nitrogen $(N)$ fixation are the key to successful development of hill country pastures (Lambert et al. 1983). Thegrazing animal, by improving utilisation and increasing nutrient cycling, was for a long time also thought to play an important part in the development sequence (Suckling 1975). But the grazing animal can cause substantial $\mathrm{N}$ losses from a pasture, in effect slowing or limiting the build up of fertility and the pace of development (Ball 1982). The animal causes losses of $\mathrm{N}$ by transfer in dung and urine from large parts of the grazed sward; losses of $\mathrm{N}$ by volatilisation from urine patches; losses of $\mathrm{N}$ by leaching from dung and urine patches; and denitrification losses associated with the biological transformations of $\mathrm{N}$. Limiting such $\mathrm{N}$ losses intheinitialyearsofdevelopmentmighthastenthebuild up of sward productivity.

Leaving a pasture ungrazed or fallowed offers one method for accelerating the build up of soil organic N. Fallowing is an ancient means for conserving soil moisture, building up nutrient levels, controlling undesirable weeds and restoring or at best permitting break down of poorly structured soils.

A sabbatical or, pastoral, fallow often involves the 'spelling' of a pasture from early spring (August/ September) to autumn (April/May). During the fallow much organic matter (plant litter) is returned directly to the soil surface. This includes nearly all the $\mathrm{N}$ fixed each year by legumes. The accumulation of organic $\mathrm{N}$, as plant litter, continues until the pasture is mob stocked in autumn. This 'pulse' of organic $\mathrm{N}$ returned in the plant litter over the fallow might improve winter and spring production after the fallow. In the longer term the soil's improved $\mathrm{N}$ status might ensure more effective use of applied fertiliser.

This study evaluates apastoral fallow for improving low fertility hill country pastures.

\section{Materials and methods}

Site

Established at 'Ballantrae', DSIR Grasslands Hill Country Research Station, near Woodville. the trial covers 2.2 ha of moderate to steep hill country, split on a north and south aspect. The soil is a YGE/YBE intergrade (Typic Dystrochrept). No fertiliser had been applied in the previous 10 years. Pastures are dominated by low fertility pasture species (browntop, sweet vernal, suckling clover and lotus).

\section{Trial design}

Five treatments were replicated 3 times on a south face and twice on a north. Individual plot were 0.05-0.08 ha. Only results from the south face arepresented. Treatments were: 1) No fertiliser and grazed (NFG); 2) Fertiliser and grazing (FG); 3) No fertiliser and fallowed in year 1 
(1989/90) (NFFY 1); 4) Fertiliser and fallowed in year 1 (1989/90) (FFY 1); 5) Fertiliser and fallowed in year 2 (1990/91) (FFY2).

North Carolina reactive phosphate rock $(35 \mathrm{~kg} \mathrm{P} /$ $\mathrm{ha} / \mathrm{yr}$ ) and elemental sulphur (14 kg S/ha/yr) were applied annually to each of the fertilised plots in August. All grazed plots were rotationally grazed with sheep and cattle. Fallow plots were dosed to grazing in September of each year and left ungrazed until May in 1989190 and A pril in 1990191. At the end of each fallow, plots were mob stocked with mixed-aged breeding cows for 2 days, spelled for 2 weeks, and then mob stocked again for 2 days. Grazed plots, as with fallowed plots after mob stocking, were grazed with sheep and cattle.

\section{Measurements}

Exclusion cages $\left(0.5 \mathrm{~m}^{2}\right)$ were used to measure pasture andlegumeproductionand total above-groundbiomass. Cages were rotated around 10 marked sites on moderate (15 to $20^{\circ}$ ) slopes on each plot. Pasture production was measured by autting to $\mathrm{I}-2 \mathrm{~cm}$ above ground level and total biomass by cutting a $0.2 \mathrm{~m}^{2}$ quadrat to ground level. Sampling times were chosen to coincide with critical periods during the fallow, including the start of the fallow, late spring, immediately after a spring trampling by stock, immediately before and a short time after autumn mob stocking. Legume (stolon and leaf), grasses (leaf, stem and seedhead), weeds (species) and dead matter content were dissected out of pasture and biomass samples. In May 1990 before the end of the fallow, the quantity and distribution of root biomass under grazing (FG) and under a fallow (FFY 1) were measured by taking $750,10 \mathrm{~mm}$ diameter cores to a depth of $\mathbb{Z} \mathrm{cm}$ from each plot.

Soil carbon (C) and $\mathrm{N}$ mineralisation, and various $\mathrm{C}$ and $\mathrm{N}$ pools, were measured with field-moist samples taken from each of 10 peg sites on each plot to a depth of $50 \mathrm{~mm}$.

In 1990/91, N fixation rates were measured on all plots by acetylene reduction. 14 soil cores to a depth of $75 \mathrm{~mm}$ were taken from each plot and incubated in an Agee-jar for $1 \mathrm{~h}$ in the presence of acetylene before a gas sample was removed and the amount of ethylene produced measured.
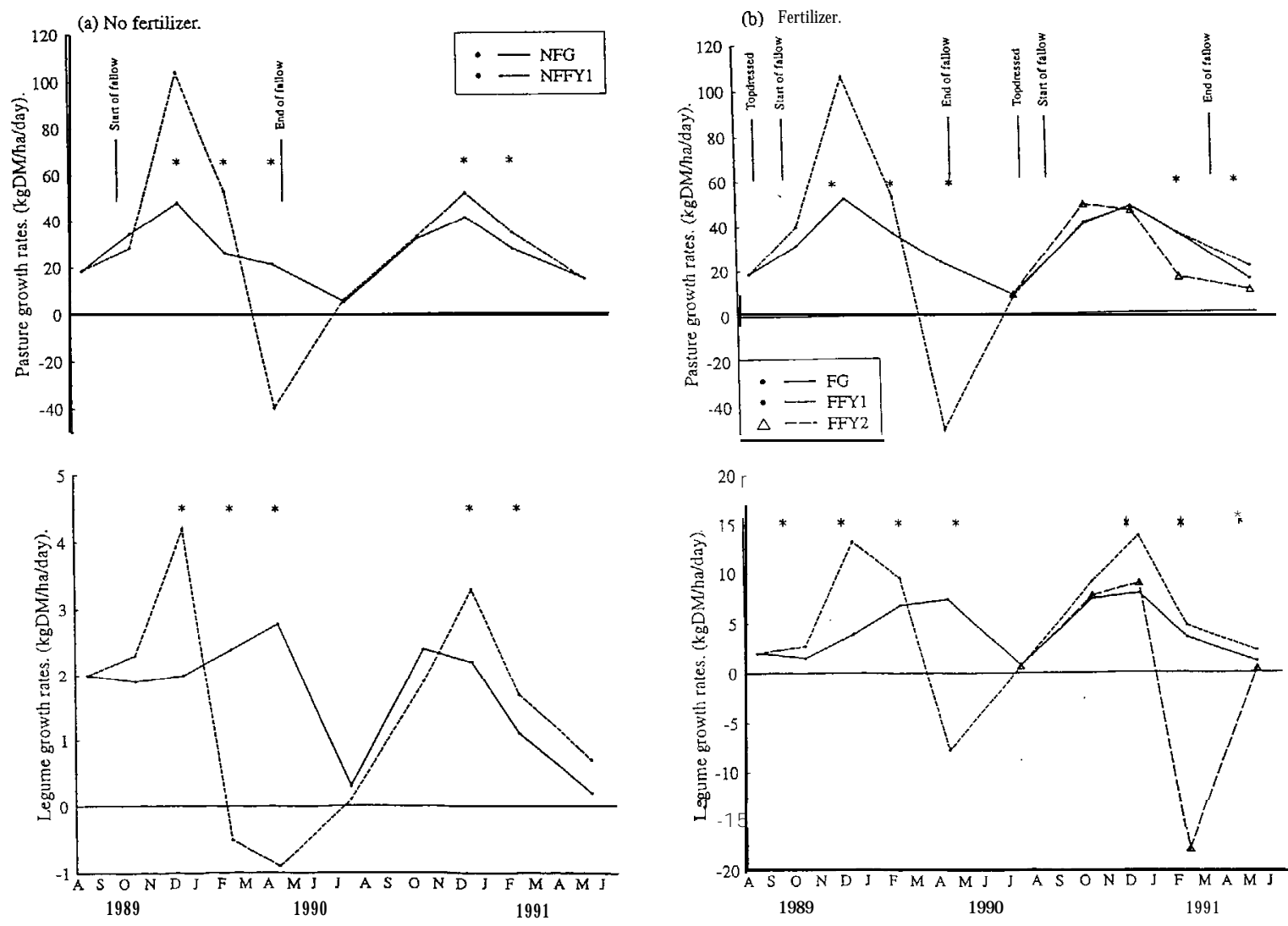

Figure 1 Effect of a fallow (a) without fertiliser or (b) with fertiliser on pasture and legume growth in the year of the fallow and in the year following the fallow. NFG = No fertiliser and grazed; NFF $1=$ Feniliser and fallowed in 1989/90; and FFY2 = Fertiliser and fallowed in 1990/ 91. *A sterisk denotes differences between treatments at the $5 \%$ level of significance. 

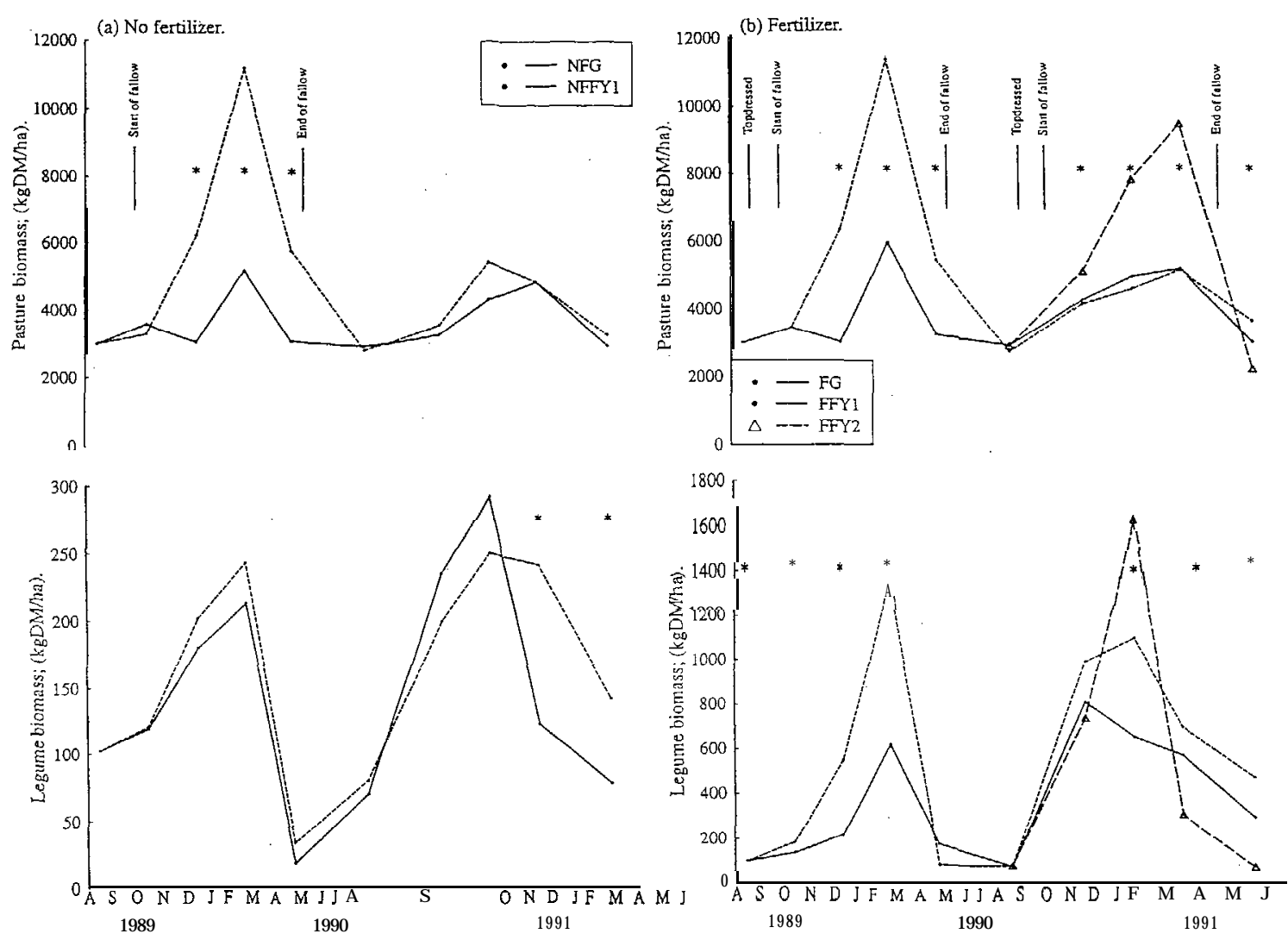

Figure2 Effect of a fallow (a) without fertiliser or (b) with fertiliser on pasture and legume biomass in the year of the fallow and the year following the fallow.

\section{Results and discussion}

\section{Impact of a pastoral fallow without fertlliser}

Pasture growth rates on NFFYl peaked at $104 \mathrm{~kg}$ DM/ ha/day in January 1990, morethan twicethegrowthrates measured on NFG during that period (Figure 1 a). Total pasture biomass reached over $11000 \mathrm{~kg}$ DM/ha in late January (Figure 2a). A net loss of DM (40 kg DM/ha/ day), as both grass and legume decomposed, was measured on the fallow treatment by late A pril/ May (Figure la), although standing biomass still exceeded $5000 \mathrm{~kg} \mathrm{DM} / \mathrm{ha}$ (Figure 2a).

The fallow did not affect the size of various soil $C$ and $\mathrm{N}$ pools, although high within-treatment variability would have obscured any small changes. Results did, however, strongly suggest thatmineralisationoforganic $C$ was stimulated shortly after the end of the fallow and the trampling of herbage by cattle. Rates of $\mathrm{N}$ mineralisation were very variable within all treatments and caused difficulties in the interpretation of the laboratory data. However, the net release of mineral $\mathrm{N}$ from plant residues and soil organic $\mathrm{N}$ also appears to have been stimulated by the fallow. This enhanced production of mineral $\mathrm{N}$ occurred much later than did the flush in C mineralisation, and would probably have been preceded by appreciable immobilisation of the mineral $\mathrm{N}$ initially released in this low-fertility soil.

Legume growth rates were lower in the winter and spring after the fallow, but by January of 1991 both legume and pasture growth rates were higher on the pasture left fallowed the previous year (Figure la). The positive effect of the fallow was also reflected in greater legume biomass in late summer and autumn of 1991 (Figure 2a) and a trend for improved N fixation throughout the 1990/91 growing season (Figure 3). The absence of any difference in total pasture biomass between NFG and NFFYI in summer and autumn in the year(1990/91) afterthefallow (Figure 2a)suggests that the increased pasture growth rates (Figure la) reflect not only the positive effect of increased $\mathrm{N}$ fixation on $\mathrm{N}$ supply, but also a change in the harvest index of the fallowed sward. By the end of the fallow in May 1990, tiller densities had declined by nearly $50 \%$ on the fallowed plots, resulting in a more open and erect sward. 


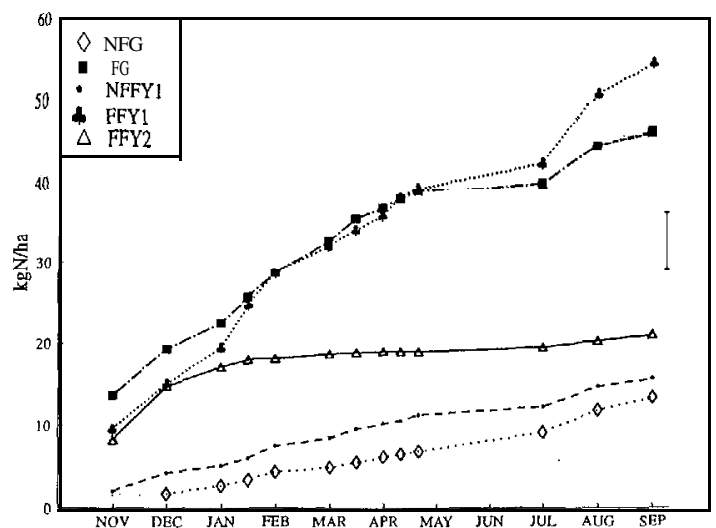

Figure 3 Effect of a fallow and/orfertiliser addition on the cumulative amount of nitrogen fixed in 1990/91. The vertical bar indicates LSD value at the $5 \%$ level.

Grass and legume species set seed during the fallow, but the seedlings established in the base of the fallowed sward in the months after the end of the fallow did not persist to contribute topasturcproduction. In late winter and early spring after the fallow white clover stolons invaded the bare ground left by the decomposing plant litter. This created niches for white clover to establish and grow and appears to be one of the major effects of the fallow on sward dynamics.

\section{Combining a fallow with fertiliser addition}

Combining a fallow with the addition of fertiliser, which alone increased legume growth rates 3 fold in summer of both $1989 / 90$ and 1990/91 (Figure $1 \mathrm{lb}$ ) and $\mathrm{N}$ fixation 5 7 fold in summer of 1990/91 (Figure 3), had an additive effect on legume growth in late spring and early summer in the year of the fallow (Figure lb). By the end of the fallow, plots both fallowed and fertilised had 56\% more plant root biomass to a soil depth of $22 \mathrm{~cm}$ (Figure 4). The effects of fallow on rates of soil $\mathrm{C}$ and $\mathrm{N}$ mineralisation were similar to those in the unfertilised treatment. The positive effect of the fallow in the year after the fallow was again reflected in improved legume growth (Figure $\mathrm{lb}$ ). The amount of $\mathrm{N}$ fixed on FFY1 compared with FG tended to increase slowly from summer 1990/91 through to spring 1991 (Figure 3).

The fallow had anegative effect on legume growth in the winter and spring after the fallow (Figure lb). This was also reflected in lower $\mathrm{N}$ fixation rates by legumes on FFY1 in the spring after the fallow (Figure 3). In fact, the effect of the fallow on $\mathrm{N}$ fixation rates was apparent within 3 months of starting the fallow (Figure 3). Nitrogen fixation on FFY2 peaked in mid-December at $0.22 \mathrm{~kg} \mathrm{~N} / \mathrm{ha} /$ day, but by late February was $<0.01 \mathrm{~kg} \mathrm{~N} / \mathrm{ha} /$ day. Interestingly, legume biomass continued to accumulate until late January in 1991 on FFY2 (Figure 2b), at which time there was more than $1600 \mathrm{~kg}$ DM/ha. This compares with only $625 \mathrm{~kg} \mathrm{DM} / \mathrm{ha}$ on FG. Nitrogen fixation rates in late January 1991 on FFY2 and FG were 0.07 and $0.20 \mathrm{~kg} \mathrm{~N} / \mathrm{ha} /$ day, respectively, suggesting that without defoliation, recycling of $\mathrm{N}$ in the legume on fallowed plots reduces the need for fixed N. An accumulation of soil in organic $\mathrm{N}$ in fallowed plots would also inhibit $\mathrm{N}$ fixation.

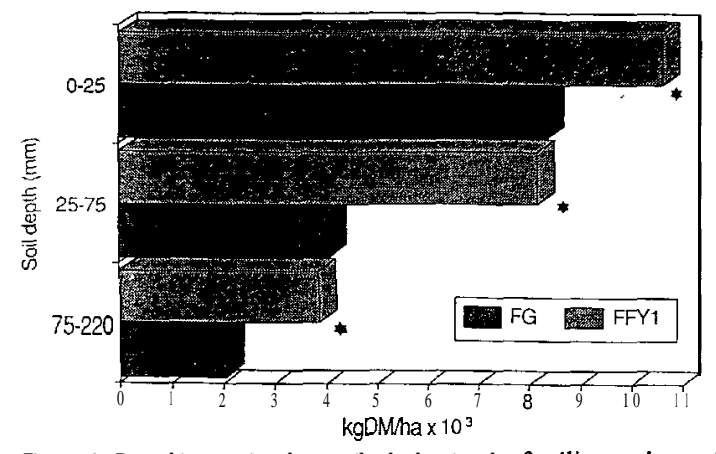

Figure 4 Root biomass in three soil depths in the fertiliser and grazes (FG) and fertiliser and fallowed (FFY1) plots at the end of the fallow in May 1990. * Asterisk denotes differences between the two treatments at each depth at the $5 \%$ level.

\section{Duration of a pastoral fallow}

A pastoral fallow often runs from spring through to late autumn. Starting the fallow later than September and finishing earlier may offer a solution for reducing the negative effect of the fallow on legume growth, while retaining its benefits for improving legume and pasture growth in the year after the fallow. On a Taranaki dairy pasture (Thomson, N. pers. comm.) a mini-fallow from October to February increased vegetative recovery of the sward, breakdown and decomposition of plant litter, and survival of seedlings, compared with an October to May fallow. Thomson (pers. comm.) also suggested that delaying mob stocking till May can lead to a severe $\mathrm{N}$ deficiency in the sward in the following winter and spring. In the present study the fallow in 1990/91 was mob stocked in April rather than May in 1989/90 in an attempt to speed up the vegetative recovery of the sward and decomposition of plant litter in the months after the fallow. A later start to the fallow and an earlier end than April/May needs further investigation. Shortening the fallow from mid-November to March would fit in more closely with the grazing management often advocated, but rarely used, for maintaining pasture control and quality in 'summer-moist' hill country in late spring and summer. Combining the benefits that accrue from good 
Table 1 Possible benefits of a pastoral fallow in different pastoral farming systems.

\begin{tabular}{|c|c|c|c|c|c|c|c|c|c|}
\hline \multirow[b]{2}{*}{ Farming System } & \multicolumn{2}{|c|}{ Sward Vigour } & \multicolumn{2}{|c|}{ Nitrogen } & \multirow{2}{*}{$\begin{array}{l}\text { Improved } \\
\text { entilisef } \\
\text { vse }\end{array}$} & \multirow{2}{*}{$\begin{array}{l}\text { Pasturea } \\
\text { Control }\end{array}$} & \multirow{2}{*}{$\begin{array}{l}\text { Pest? } \\
\text { Control }\end{array}$} & \multirow{2}{*}{$\begin{array}{c}\text { Soill } \\
\text { fauna }\end{array}$} & \multirow{2}{*}{$\begin{array}{c}\text { Soil } \\
\text { physical } \\
\text { properties }\end{array}$} \\
\hline & Re-se日ding ${ }^{1}$ & Re-generation' & Accumulation' & Conservation ${ }^{4}$ & & & & & \\
\hline 1. Low fertility hill country & 1 & 4 & 5 & 2 & 5 & 5 & $?$ & + & + \\
\hline 2. Hill country & 2 & 4 & 3 & 3 & 5 & 5 & $?$ & + & + \\
\hline 3. Intensive sheep/beef & 3 & 4 & 2 & 2 & 2 & 4 & $?$ & + & + \\
\hline 4. Mixed cropping/fattening & 0 & 0 & 2 & 5 & 1 & 1 & $?$ & + & + \\
\hline 5. Dairying & 4 & 4 & 2 & 2 & 2 & 3 & $?$ & + & + \\
\hline
\end{tabular}

Re-seeding. $1=$ little or no reseeding; 5 = extensive $\mathrm{m}$-seeding.

Re-generation. Reduce tiller density, increase tiller size and individual plant size and vlgour. Increased rooting depth. $1=$ minor: $5=$ major effect.

3 Nitrogen accumulation. Return of $\mathrm{N}$ as plant litter to the site of fixation. $1=$ minor improvement; $5=$ significant.

4 Nitrogen conservation. Reduce the losses of $\mathrm{N}$ by providing a carbon source. $1=$ minor role; $5=$ significant.

$5 \quad$ Improved fertiliser use. Reduce $S$ and $P$ losses by transfer In dung and urine. 1 minor role; $5=$ significant.

6 Pasture control. Management tool for maintainlng pasture quality. $1=$ minor role; $5=$ significant.

Pest management. Impact on porina and grassgrub populations. Ranking - + Positive; - Negative effect.

- Soil fauna. Increase in earthworm and Enchyt. numbers. + Positive; - Negative effect.

- Soil physical properties. impact on surface soil bearlng strength; infiltration rates, etc. Ranking - + Positive: - Negative effects.

\section{Time of fallow:}

A For systems 1, 2, 3 and 5, a traditional spring to autumn or summer-only (mini-fallow), although in drier areas of the country an autumn to summer fallow may be more effectlve.

B. For system 4, a summer to spring fallow may be more appropriate.

summer pasture control and fallowing offers an exciting management tool for hill country farmers.

\section{Benefits of a pastoral fallow}

In this study legume growth and $\mathrm{N}$ fixation improved in the year after the fallow only (Table 1). In contrast, in an intensive dairying system the major benefit of a minifallow (October to February), more commonly referred to as a non-conservation or a deferred grazing practice, was the regenerating and reseeding of the dominant grass species (Thomson, N. pers. comm.). Improved legume production and better conservation of fixed $\mathrm{N}$ appear to be of less significance in this farming system.

Fallowing may offer a method for accumulating and, more importantly, conserving $\mathrm{N}$ for the cropping phase in a mixed cropping and fattening operation. Crop responses to fertiliser $\mathrm{N}$ in the first 2 years out of a permanent pasture are often small and uneconomic, but the losses of $\mathrm{N}$ by leaching as nitrate during this period can often exceed the total $\mathrm{N}$ uptake by the crop (Carran 1990). Reducing these losses by using a fallow to add a large pulse of $\mathrm{C}$ to the soil may offer in the short-term a method for retaining $\mathrm{N}$ in the organic fraction and in so doing reducing nitrate leaching losses. Slowing or reducing the initial $\mathrm{N}$ loss might extend the cropping phase.

\section{ACKNOWLEDGEMENTS}

Vanessa Pokaia for technical assistance, Fay Pedley and James Evans for $\mathrm{N}$ fixation measurements and Yvonne Gray, Margaret Greig and Chris tine Van Meer for herbage dissections.

\section{REFERENCES}

Ball,P.R. 1982. Nitrogen balances in intensively managed pasture systems 'Nitrogen balances in New Zealand Ecosystems, Proceedings of Workshop on Nitrogen balances in Terrestrial Ecosystems inNew Zealand. Palmerston North, May 1980, pp 47-66.

Carran, R.A. 1990. Dynamics of soil andplantnitrogen in cultivated and no-till spring wheat systems following old pastures. NZ Journal of Crop and Horticultural Science 18: 5-9.

Lambert, M.G.; D.A.Clark, D.A.; Grant, D.A.; Costall, D.; Fletcher, R.H. 1983. Influence of fertiliser and grazing management on North Island moist hill country. NZ Journal of Agricultural Research 26: 95-108.

Suckling, F.E.T. 1975. Pasture management trials on unploughable hill country at Te Awa. III. Results from 1959-1969. NZ Journal of Experimental Agriculture 3: 351-436. 